\title{
University Academic Work: Analysis of Collegiate Structures
}

\author{
Hilda García-Castillo ${ }^{1 *}$, Ivett Reyes-Guillén ${ }^{2}$, María-Eugenia Estrada-Álvarez ${ }^{1}$ \\ ${ }^{1}$ Professor-Researcher, Administrative Sciences School, Campus IX Arriaga, Autonomous University of \\ Chiapas, Mexico, Carretera Arriaga-Tapanatepec Km. 1, Arriaga, Chiapas México \\ ${ }^{2}$ Professor-Researcher, Social Sciences Faculty, Campus III, Autonomous University of Chiapas, Mexico. \\ Member of the academic corps, society, culture and education Research line: Cognitive analysis for the \\ interpretation of social processes and development. Society, Sustainability and Health. Calle \\ presidenteobregón s/n Fracc. Revolución Mexicana
}

*Corresponding Author: Hilda García-Castillo, Professor-Researcher, Administrative Sciences School, Campus IX Arriaga. Autonomous University of Chiapas, Mexico. Carretera Arriaga-Tapanatepec Km. 1, Arriaga, Chiapas México

\begin{abstract}
This article presents results of an investigation whose objective was the analysis of the status of collegiate structures of academic work at the university level, from the perspective of the administration theories. The study is qualitative, descriptive and analytical transversal type carried out during the period October 2016 to August 2017 in Chiapas, México. The information was obtained through structured survey applied to professors-university researchers. One of the policies aimed at promoting new ways of stimulating the generation and application of knowledge has been the impetus to the creation of academic corps $(C A)$ in the public institutions of higher education. The main objective of these policies is to strengthen the academic dynamics supported by collaborative work. However, it has been limited to consider purely mechanical, organizational integration elements in the operational part; but little has been stopped to analyze the complex human interaction and the ease of an optimal social climate. Is necessary the development of competencies and skills, preparing at the individual and collective level.
\end{abstract}

Keywords: Collegiate structures, University, Administration theories, Maslow

\section{INTRODUCTION}

Most of the scientific, technological and humanistic research in Mexico is developed in the Institutions of Higher Education (IES) and the capacities for the generation and application of the knowledge, as well as for the formation of researchers are insufficient. In addition, they are distributed unevenly in the national territory and their development in many dependencies limits the possibilities of contributing to the social and economic development of the country (Rubio, 2006).

Within the universities or IES, professors, in addition to attending and participating in the development of educational programs, must also generate or apply knowledge thus ensuring its permanent updating and transfer of current knowledge to students enrolled. That is why teachers must group for collective academic development, making sure to share one or several lines of generation or application of knowledge (LGAC) developing disciplinary or multidisciplinary areas, under the structure of academic corps (CA).

These groups are formed with full-time professor (PTC) of the IES, within the framework of the guidelines of the program for the Professional Development of Professors (PRODEP), who has given to the universities, opportunities to strengthen their academic plants, through their Productions in an individual and collective way.

Schools and faculties belonging to the Autonomous University of Chiapas (UNACH), as in other institutions of higher education, are integrated by PTC, part-time teachers, trusted staff, subject teachers and Academic technicians. This integration allows the behaviors of each one of them to be different considering their different perceptions regarding the working environment (SPAUNACH, 2016). Because of this diversity of contractual forms, the formation of academic corps in some of the faculties or schools that make up the university is difficult. 
The main objective of the present study was the analysis of the status of collegiate structures of academic work at the university level, from the perspective of the administration theories. The above, taking as a case study to the Administrative Sciences School, UNACH. In this institution the problem is exacerbated, when considering that the academic production by the PTC is minimal or nil. It is understood by academic production to participate in research projects, publication of books, chapters of books, Articles with scientific quality, participation in national and international congresses.

\section{RESEARCH METHOD}

\subsection{Type of Study}

The present study is of qualitative, descriptive and analytical transversal type carried out during the period October 2016 to August 2017.

\subsection{Study Population}

Full-time teachers (PTC) Administrative Sciences School Campus IX Arriaga and Tonala of the Autonomous University of Chiapas, Mexico.

\subsection{Information Gathering Technique}

Through a structured survey applied to teachers of the school of Arriaga and Tonala, with interest in variables a) individual production and B) conformation of collegiate structures of academic work in Administrative Sciences School.

\subsection{Sample Size}

Administrative Sciences School, Campus IX Arriaga: $n=7$ research-professor. Administrative Sciences School, Campus IX Tonala: $\mathrm{n}=11$ research-professor

\section{RESUltS}

\subsection{Administrative Sciences School, Campus IX Arriaga}

Seven interviews were applied in this school. The teachers surveyed are attached to the School of Administrative Sciences Campus IX headquarters Arriaga.

For the most part (67\%), they carry out a research project a year, the remaining percentage (33\%) carry out two annual projects, with a periodicity of six months each. All are PTC and the research is within the activities of their job category.

In the LGA Care considered topics such as:

- Sustainable development

- SME Organization

- Development and Regional Sustainability

- Local Development and innovation

- Local production systems

- Development of human talent management

The impact of research is measured in spaces such as:

- Food security

- Agricultural production deficit in Mexico, Chiapas and the Frailesca Region

- Problems of productive projects financed by the Federal Government

- Productionand commercializationof cattle

- CommunityLeadership

In a specific way in connection with the environment, Administrative Sciences School has impact on the development of the municipality of Arriaga, Chiapas, in the following points:

- The process of restructuring the productive chain Corn-Tortilla in the Central Region of Chiapas 
- Corn-Tortilla; Sustainability and food security

- Public financing to the productive system

- Tourism development strategies of Playa Aventura

- Production and commercialization of cattle in the municipality of Arriaga, Chiapas

- Leadership as a success factor in rural organizations

- Management of human talent in the cheese-producing industries

Although the Administrative Sciences School teachers have productivity in research and intervention, only two of them belong to an academic corp. In the search for the reasons why there is no CA in the school, the teachers interviewed commented that it is required:

- PTC's liability

- Vocation to investigate

- Availability to do collaborative work

- Honesty in collaborative work

- Academic cooperation

- Define common or complementary research areas

- Know the guidelines of the Secretariat of Public Education (SEP), state system of researchers (SEI) and national system of researchers (SNI)

- Learn about quality academic production

\subsection{School of Administrative Sciences, Campus IX Tonala}

Eleven interviews were conducted in total to research-professor. The Administrative Sciences School in Tonala has specific lines of research related to the needs that are presented in the social environment, these are:

- Management for development

- Local development

- Local production systems and rural tourism

- Higher education in the 21 st century

- ICT implementation in public and private areas

They carry out semester or yearly research, and they are inclined by the development of units of educational linkage (UVD), projects of investigation-intervention in which the students are involved in a formal manner.

The impact of their research is marked by:

- Livestock Sector

- Turismo Rural

- Rural women entrepreneurs who market fish on the periphery of the public market

The areas that have been strengthened by research, impacting the municipality of Tonala are:

- Socioeconomic study of the livestock sector

- Socio-economic relations of the tourism productive system of the Costa Chica of Chiapas

- Marketing of fish as a detonator to the economic empowerment of women

- Artisan House to produce memelitas and potatoes, work of rural women

For the formation of academic corpswith the teachers is required: 
- Integration and prevail institutional interest before personal interests

- Strengthening on the part of the institution

- Quality academic production on an individual basis and a collective academic work

- Working together, in harmony, enhancing teamwork that benefits the university in general and to the personal development

\section{ANALySis AND CONCLUSIONS}

In the analysis of the results found two moments arise. The first corresponds to the strength and weakness that PTC perceive for the formation of academic corps and what it implies in their academic growth.

The second, in relation to cultural necessities, temporal space and elements that from the administration are considered as determinants of the success or failure in the conformation of academic corps within the university field.

\subsection{Perception of the PTC of Administrative Sciences School, Arriaga and Tonala, for the Formation of Academic Corps and what Implies in their Academic Growth}

Within the Administrative Sciences School, Arriaga and Tonala, research has clear lines of interest, such as:

- Local development

- Rural tourism

- Local and regional marketing

- Women's empowerment in local marketing areas

They also have important local and regional linkages and impact by strengthening cooperative work with:

- Livestock Sector

- Tourism production System

- Local trade

- Leadership in rural trade

Another of the strengths is to have teachers with doctor degree and research trajectory, as well as interest in research and intervention in the area of influence of schools.

Within the weaknesses, they are considered as such:

1. Absence of organization of work by team

2. Lack of collective commitment

3. Need for institutional support

4. Training is required for knowledge of the processes of conformation and monitoring of the different access platforms to PRODEP

The elements that they consider important to achieve the conformation of academic corps can be listed as:

- To have the preparation and vocation to carry out research

- Willingness to do collaborative work

- Honesty in the collective work

- Knowledge of the PRODEP guidelines

- Have quality academic production

- Avoiding intellectual egocentricity 


\subsection{Cultural Needs Temporal Space and Elements of the administration as determinants of Success or Failure in the Conformation of Academic Corps within the University Field}

Research is a fundamental part of teaching; it is necessary and complementary during the training of both the academic and the students. However, talking about research, interdisciplinary, disciplinary egos and intellectuals, we are already in the area of human relations and becomes a difficult space to understand.

If to the above, we add the cultural traits of the teachers-researchers, it is necessary to stop the look to the understanding and search of solution to healthy ways to relate academically for a common good, the institutional production, even more if it is a Higher-level educational institution.

It is necessary to accept that each discipline and each teacher-researcher will contribute different modes of observation, analysis and generation of knowledge. As well as different ways of following the academic trajectory and the formation of students.

It is also necessary, to have a flexible thinking, cognitive skills, research and linkage, communicative and integral competences that facilitate the use of the disciplinary strengths and limitations, of the collegiate groups and academics corps and the same institution of belonging.

The foregoing allows us to integrate to produce; It also increases the capacity for critical thinking and develops humility. The academic activities of disciplinary integration contribute to strengthen values and competencies in teachers and students (Carvajal Escobar, 2010), elements that are undoubtedly being requested in both schools where the present study was developed.

In addition, it is important to recognize the spatial location of the schools, when it is clear the educational backlog in which Chiapas is compared to the rest of the country. Knowing further that this affects not only the teaching-learning process but specifically the sensitivity of the efforts that researchers make even with all these constraints involved in having a negligible human development index (HDI).

It is important to mention the influence of psycho-social factors, closely related to symbolic construction factors of importance. Psychosocial factors are connections that occur between the person and society. This dimension includes variables that measure some personality traits that might be associated with performance, such as motivation, anxiety, self-esteem in labor, academic contexts, and the perception of the social and organizational climate of their Institution.

There is a partnership between motivation and performance. This means that, to the extent that the teacher-researcher shows more interest in what he does, and his aspirations conform to his possibilities, he will be more motivated, and this results in better production and academic projection.

On the other hand, anxiety and other personal characteristics inhibit the work performance, in this case academic. It is also of importance to consider aspects related to the self-concept that arises from the interrelation of three instances: Auto image, social image and ideal image.

The foregoing may explain the teachers ' expressions in the sense of the need for cooperative work values, collective production and specifically to avoid intellectual egocentricity. The panorama of what is your ideal image as an organization. The academic performance not only depends on the intellectual capacity of the person, but also on emotional competencies to manage itself and its environment (Montero et al, 2007).

\subsection{The Paradox of Quantity and Quality in Countries like Mexico and States like Chiapas}

At the end of the twentieth century, in the decade of 1980, enrollment growth in most Latin American countries was evident. Growth in quantity was not directly proportional to the quality of education. There has been investment and maintenance in infrastructure and equipment; But it is until last years that it has been considered the importance of qualitative indicators for the measurement of the quality of education (Rodríguez, 2001).

In a globalized world, there is a need for structural and cultural changes for the countries of the region; Not only in terms of the globalization of markets, the release of tariffs and standards, but also in terms of productivity and competitiveness and, above all, quality. 
In countries of the Latin American region there are still strong shortcomings in aspects of housing, health, employment, education. With regard strictly to the expansion of the education system, it has always been more important to show growth in absolute and relative numbers. There are No correct ways to measure school performance, access to the labor market, curricular and didactic innovation, among other aspects, aspects that must be measured or evaluated from a qualitative perspective as well. The above can then be one of the most delicate challenges for the IES in question of correctly evaluating the quality indicators, considering that the reality of the user and the providers of the educational service is the sum of variables Quantitative and qualitative.

That is to say, the challenge of quality is not limited to the quantitative measurement of what the user can obtain, but also in the ways in which the providers of the educational service are built and rebuilt to achieve quality in the educational, organizational processes and social realities that constitute the reality of education and in this case of university education.

It is then that the creation of academic corps is an option to improve the quality and quantity in the production of the PTC in universities; But the context refers us to consider a condition of lagging not only educational, but social of great importance, same that generates weakness in the collective work, since the priorities of the individual student or professional, are limited to the base of the pyramid of Maslow (Maslow 1943; Colvin and Rutland, 2008), that is to meet the basic necessities.

The real improvement in the educational quality, in the teaching-learning process, of any educational level, can be given if and only yes, the basic necessities are covered, it is transited by the social necessities that define a collective identity with impulse to sustainable development; And also, to consider the insertion of the student to educational programs of university level having traveled by a basic educational level of quality.

For this study, talk about quality, quantity and conformation of academic corps at a university in southeastern Mexico, with low human development index, has priorities, within them and listed by the teachers who participated in the study: 1) Have the preparation and vocation to carry out research; 2) Willingness to perform collaborative work; 3) Honesty in collective work; 4) Knowledge of the PRODEP guidelines; 5) Quality academic production and 6) Avoid intellectual egocentricity.

One of the policies, globally and Mexico is no exception, aimed at promoting new ways of stimulating the generation and application of knowledge has been the impetus to the creation of academic corps (CA) in public institutions of higher education. The main objective of these policies is to strengthen the academic dynamics supported by collaborative work. However, it has been limited to consider purely mechanical, organizational integration elements in the operational part; but little has been stopped to analyze the complex human interaction and the ease of an optimal social climate.

This investigation analyzed the production of research in the Administrative Sciences School, Campus IX Arriaga and Tonala, Autonomous University of Chiapas, its strengths, weaknesses and its impact towards the society.

It is important to explain that some PTC from both schools have research-based academic production; but they have not followed a collective academic development. Even though the university legislation and the teacher'sstatute provide for the teacher to carry out research that is linked to regional development, in both schools there are PTC who do not perform any kind of Research and its academic production is nil.

In every organization, collective and individual interests are present, however, for this study, one of the main results is to consider that each worker carries out his activities based on his personal interests and meets the minimum requirements of their functions. Therefore, the research is carried out only if there is economic compensation, a reality that we can understand if we review the Maslow pyramid (Wahba and Bridwell, 2004), where the basic necessities are the basis and, in this case, the apex where the needs of self-realization, i.e. potential development, are to be reflected, is limited to remuneration and not to professional self-realization and commitment Social.

Based on Maslow we can say that, university professors need to redefine their social or belonging needs, that is, they require a closer interest with the institution in which they work. At the same time, it is necessary to locate that being in a country and a state like Chiapas, Mexico, with very low impact of human development, this becomes highly complex. That is, how to envision social needs and, in 
other words, how to envision the needs of self-realization if we do not have the solvency of necessities.

On the other hand, how can we talk about a glimpse of the needs of self-realization in the academic world if the surrounding reality speaks of a country where one of the weakest indicators, when evaluating its level of human development, is education. Mexico records a lower schooling than that of African countries such as Botswana and Rwanda, according to figures from the United Nations Development Program. Mexico is located in place 71 (of 187 countries assessed) in the 2014 edition of the Human Development Index (HDI), which considers the following variables: Life expectancy, years of middle schooling (years on average have studied adults), expectation of schooling (years estimated to be studied by children who begin their education) and per capita income (PNUD, 2016).

This discussion is deserving of a specific study and finding ways of care for university teachers and comprehensive educational development programs.

However, in the case of the school of Tonala, its teachers have formed collegiate groups, which must be registered with the Directorate General of Research and Postgraduate (DGIP), organ belonging to the UNACH. The link with DGIP will allow you to grow in the development of your collective activities. It is also before this body that they must register their investigations, with the purpose of formalizing with requirements of the PRODEP. At this point it is also important to emphasize the need for a program of approach of the DGIP for the training of teachers in the improvement of the academic quality of them, according to their functions as PTC.

The teachers of both schools have learned other forms of organization in collective and collegiate research, since they have gradually been conducting individual and collective research work. Their personal relationships have improved and allow them an increasingly healthy and productive interaction.

Is important to conclude by analyzing the training of effective teachers. Among the most important characteristics of effective teachers, are included (Hunt, 2009):

- Motivation

- Knowledge of the topic

- Time in the profession or experience

- Professional vocation

It is also necessary to clarify that a teacher may be affected by the administrative decisions of the institution where he works, for example, school curricula, challenging goals and evaluation. The factors that determine their level of effectiveness, which influences individual and collective success on the process of student training, are individual decisions related to the concept that the teacher has of himself (Marzano, 2003).

Collaborative, responsible and equity-based work, between organized teachers and collectives, contributes to effective teaching and research. The advantages of working in academic corps is that you share experiences of professional practice.

Within the characteristics that must ponder the collective work of the university professors can be concluded that they are:

- Reciprocal institutional commitment

- Knowledge and management of one or more perfectly defined areas of information

- Research in line with their individual and collective interests

- Labour management and monitoring to indicate the lines of institutional development, academic corps and the development of each investigator

- Systematic reflection on their practices and learning of experience

Finally, as a final comment, it is necessary to consider that both effective leadership, effective teaching, effective research, are not innate characteristics. It is achieved through the field of the nobility of the university or educational environment in general and it is necessary the development of 
competencies, skills and skills, preparing at the individual level, at the level of academic corps and especially in a University institution.

\section{REFERENCES}

[1] Rubio, J. (2006). La política educativa y la educación superior en mexico. México: Secretaria de Educación Pública. Fondo de Cultura Economica.

[2] SPAUNACH. (2016). Contrato colectivo de trabajo. Tuxtla: talleres gráficos de la UNACH.

[3] Carvajal Escobar, Y. (2010). Interdisciplinariedad: desafío para la educación superior y la investigación. Revista Luna Azul ISSN 1909-2474 No. 31, julio-diciembre, Universidad de Caldas

[4] Montero Rojas, E., Villalobos Palma, J. y Valverde Bermúdez, A. (2007). Factores institucionales, pedagó- gicos, psicosociales y sociodemográficos asociados al rendimiento académico en la Universidad de Costa Rica: Un análisis multinivel. RELIEVE, v. 13, n. 2, p. 215-234. www.uv.es/RELIEVE/v13n2/ RELIEVEv13n2_5.htm

[5] Rodríguez GR. (2001). Educación, desarrollo y democracia en América Latina: Un balance de los noventa. Perfiles educativos, 23(94), 6-42. Recuperado en 28 de enero de 2019, de http://www.scielo.org.mx/ scielo.php?script=sci_arttext\&pid=S0185-26982001000400002\&lng=es\&tlng =es.

[6] Maslow AH (1943). "A Theory of Human Motivation”, Psychological Review, vol. 50, 1943, pp. 370-396

[7] Colvin, M. y Rutland, F. (2008). Is Maslow's Hierarchy of Needs a Valid Model of Motivation. Louisiana Tech University. Documento en línea recuperado 15 abril de 2011 de http://www.business.latech.edu/

[8] Wahba MA y LG Bridwell. (2004). Maslow reconsidered: A review of research on the need hierarchy theory. Baruch College, The City University of New York USA.

[9] PNUD (2016). Panorama General, Informe sobre desarrollo humano 2016. Consultado en: http://hdr.undp.org/sites/default/files/HDR2016_SP_Overview_Web.pdf

[10] Hunt, B. (2009). "Efectividad del desempeño docente. Una reseña de la literatura internacional y su relevancia para mejorar la educación en América Latina. Programa de Promoción de la Reforma Educativa en América Latina y el Caribe [PREAL]”, (43), 1-36. Recuperado de http://www.oei.es/pdf2/documento_ preal43.pdf

[11] Marzano, R. (2003). What Works in Schools. Virginia, USA: ASCD

Citation: Hilda García-Castillo, et.al. "University Academic Work: Analysis of Collegiate Structures" International Journal of Research in Sociology and Anthropology (IJRSA), vol 5, no. 3, 2019, pp. 1-8. doi:http://dx.doi.org/ 10.20431/2454-8677.0503001.

Copyright: (C) 2019 Authors. This is an open-access article distributed under the terms of the Creative Commons Attribution License, which permits unrestricted use, distribution, and reproduction in any medium, provided the original author and source are credited. 